\title{
Detection of Merkel Cell Polyomavirus in the Human Tissues from 41 Japanese Autopsy Cases Using Polymerase Chain Reaction
}

\author{
Michiko Matsushita a, b Satoshi Kuwamoto ${ }^{a}$ Takeshi Iwasaki $^{a}$ \\ Hiromi Higaki-Mori ${ }^{a, c}$ Shoji Yashimad Masako Kato ${ }^{a}$ Ichiro Murakami ${ }^{a}$ \\ Yasushi Horie $^{d}$ Yukisato Kitamura ${ }^{b}$ Kazuhiko Hayashia \\ ${ }^{a}$ Division of Molecular Pathology, Department of Pathology, ${ }^{b}$ Department of Pathobiological Science and \\ Technology, School of Health Science, and ' Division of Dermatology, Tottori University Faculty of Medicine, and \\ ${ }^{\mathrm{d}}$ Department of Pathology, Tottori University Hospital, Yonago, Japan
}

\section{Key Words}

Merkel cell polyomavirus • Human tissues - Autopsy •

Polymerase chain reaction

\begin{abstract}
It has recently been shown that approximately $80 \%$ of Merkel cell carcinomas harbor a novel polyomavirus named Merkel cell polyomavirus (MCPyV). MCPyV has been detected in human tissue samples. However, detailed distribution of MCPyV in non-neoplastic Japanese human tissues remains unclear. To address this, we used single or real-time quantitative polymerase chain reaction (PCR) for 41 autopsy cases. PCR revealed MCPyV-DNA in non-neoplastic samples: total, 29/41 (71\%); adult, 29/39 (74\%); fetus or infant, 0/2; men, 24/28 (86\%); women, 5/13 (38\%); total human tissues, 66/572 (12\%); skin, 8/15 (53\%); adrenal gland, 9/33 (27\%), and other 16 organs (4-25\%). This study first reported the presence of MCPyV-DNA in non-neoplastic tissues of thyroid gland, adrenal gland, spleen, bone marrow, stomach, gallbladder, pancreas, heart, and aorta. PCR revealed that viral load ranged from 0.00026 to 0.22 in all MCPyV-positive tissues compared with Merkel cell carcinoma samples. These detailed PCR data showed higher prevalence of MCPyV infec-
\end{abstract}

tion in Japanese men than women $(p=0.004)$ and broad distribution of MCPyV with low viral load in more non-neoplastic human tissues than in the previous reports. These data provide valuable insights for further studies of MCPyV infection and MCPyV-related diseases.

Copyright $\odot 2012$ S. Karger AG, Basel

\section{Introduction}

Merkel cell polyomavirus (MCPyV) was recently discovered to be associated with Merkel cell carcinoma (MCC), a rare and aggressive human skin cancer [1]. $\mathrm{MCPyV}$-induced oncogenesis is thought to be involved in the transformative properties of the $\mathrm{MCPyV}$ large $\mathrm{T}$ antigen. MCPyV has been detected in MCC patients and appears to play the chief role in tumorigenesis; about $80 \%$ of MCCs harbor MCPyV [1]. Currently, the frequency of infection of MCPyV is not completely unclear. However, using real-time polymerase chain reaction (PCR), researchers have reported that $\mathrm{MCPyV}$ has been detected in normal human tissue samples such as the skin, liver, and respiratory secretion samples. Moreover, $\mathrm{MCPyV}$ has been detected in malignant and benign tis-

\section{KARGER}

Fax +4161306 1234

E-Mail karger@karger.ch

www.karger.com
(C) 2012 S. Karger AG, Basel

$0300-5526 / 13 / 0561-0001 \$ 38.00 / 0$

Accessible online at:

www.karger.com/int
Kazuhiko Hayashi, MD

Division of Molecular Pathology, Department of Pathology

Tottori University Faculty of Medicine

Nishi-cho 86, Yonago, Tottori 683-8503 (Japan)

Tel. +81 85938 6063, E-Mail hayashik@med.tottori-u.ac.jp 
Table 1. Detection of MCPyV-DNA in autopsy cases by single PCR

\begin{tabular}{lccc}
\hline & Cases & $\begin{array}{l}\text { MCPyV- } \\
\text { positive cases }\end{array}$ & $\begin{array}{l}\text { Frequency } \\
\text { of positivity, \% }\end{array}$ \\
\hline Age & & & \\
$\quad$ Fetus or infant & 2 & 0 & 0 \\
23 years & 1 & 1 & 100 \\
$\quad$ 33-88 years & 38 & 28 & 74 \\
Sex & & & 86 \\
$\quad$ Male & 28 & 24 & 38 \\
$\quad$ Female & 13 & 5 & 71 \\
\hline Total & 41 & 29 & \\
\hline$* \mathrm{p}=0.004$ & & & \\
\hline
\end{tabular}

sues [1-8]. However, previous reports on the presence of this virus in non-neoplastic human tissues have been partial and incomplete. The purpose of the present study was to elucidate the presence of MCPyV in every type of human tissue samples. Thus, we examined the samples from 41 autopsy cases. The presence or absence of $\mathrm{MCPyV}$ in each sample was evaluated by PCR and realtime PCR.

\section{Materials and Methods}

\section{Human Tissue Samples}

The study was approved by the Institutional Review Board of the Faculty of Medicine, Tottori University. A total of 41 human autopsy samples from 39 adults, 1 fetus, and 1 infant as well as reference MCC samples were obtained from the Department of Pathology at Tottori University Hospital as excess pathological tissue was not required for diagnosis. The reference MCC samples were paraffin embedded. We tested all the tissue types from the 41 individuals. A total of 572 human tissue samples were examined, 117 of these were fresh frozen; the remaining 455 samples were paraffin embedded. Of the neoplastic tissues examined, 3 were benign, and 19 were malignant tumors. A sample of liver metastasis from a rectal carcinoid tumor was fresh frozen, but the remainder was paraffin embedded.

\section{Polymerase Chain Reaction}

To detect MCPyV by PCR, DNA was extracted from each sample using the QIAamp DNA FFPE Tissue Kit and Mini Kit (QIAGEN, Hilden, Germany) according to the manufacturer's protocols. The presence of adequate DNA in samples was confirmed by measuring the internal control DNAs of RNase P. A primer pair targeting the position 859-934 on MCC350 (GenBank EU375803) [9] was used (MCPyVLT forward, 5'-AGGTTGACGAGGCCCCTAT-3'; reverse, 5'-TTCCCGAAGCTGAATCCTC-3'; amplicon size, 76 bp). PCR was performed using $1 \mathrm{U}$ of TaKaRa Ex

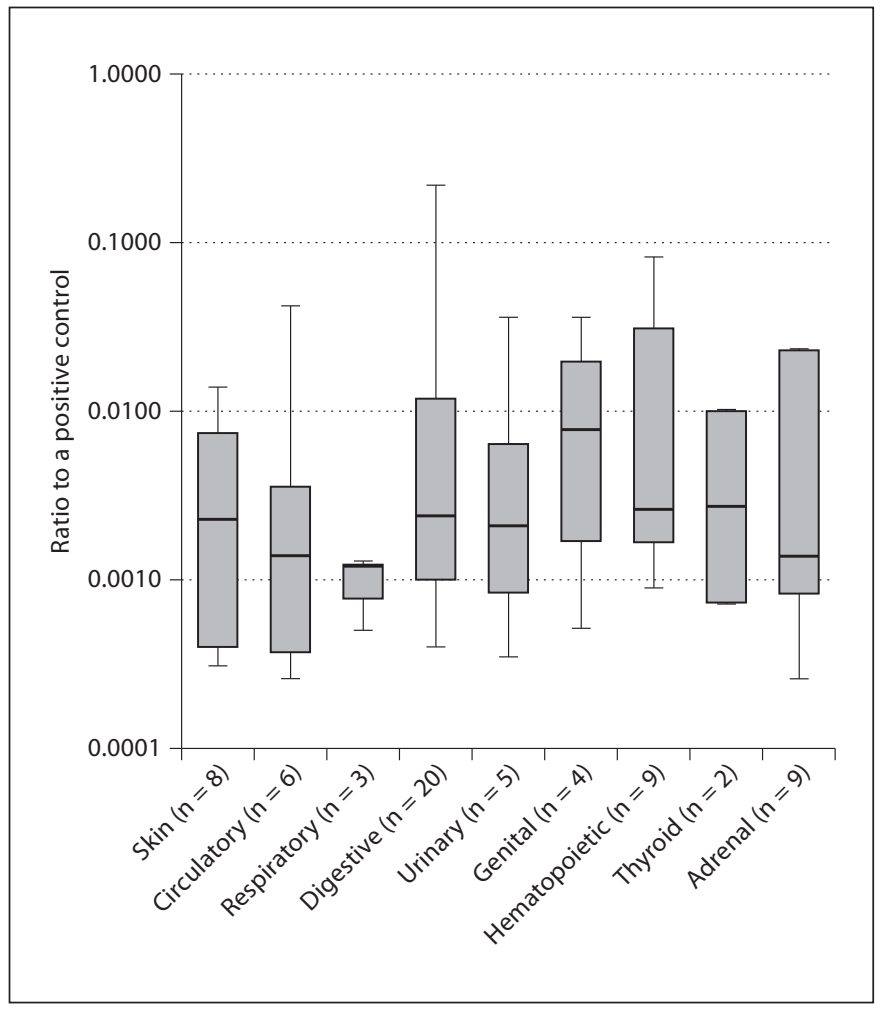

Fig. 1. Box plots show MCPyV levels relative to a reference MCC (1.0) through the different organ systems. Skin, circulatory, respiratory, digestive, genitourinary, hematopoietic and endocrine (thyroid gland, and adrenal gland) samples are shown. Box plots show the middle $50 \%$ of data, the line is the median, and the bars extend the median by 1.5 times the interquartile range. The median: skin, 0.0023; circulatory, 0.0014; respiratory, 0.0012; digestive, 0.0024; urinary, 0.0021; genital, 0.0078; hematopoietic, 0.0026 ; thyroid gland, 0.0027 ; adrenal gland, 0.0015 .

Taq HS (Takara Bio Inc., Otsu, Japan) with 30 ng of genomic DNA in $20 \mu \mathrm{l}$ solutions for each sample and the controls. The positive control was MCCs, and water was used as the negative control. Amplifications consisted of an initial denaturation for $5 \mathrm{~min}$ at $94^{\circ}$ with 40 cycles of denaturation for $30 \mathrm{~s}$ at $94^{\circ}$, annealing for $30 \mathrm{~s}$ at $59^{\circ}$, and extension for $1 \mathrm{~min}$ at $72^{\circ}$. PCR products were electrophoresed, stained with ethidium bromide, and visualized under UV light. Cases in which one primer set amplified visible DNA fragments of the expected length (76 bp) were considered $\mathrm{MCPyV}$ positive; all others were considered to be MCPyV negative.

\section{Real-Time PCR}

To determine the MCPyV-DNA ratio relative to $\mathrm{MCPyV}$-DNA of the reference MCC $(\mathrm{MCC}=1.0)$ for each case, real-time PCR was performed using an ABI PRISM 7900HT Sequence Detection System (Applied Biosystems, Foster City, Calif., USA). A total of $30 \mathrm{ng}$ of each DNA sample was amplified with $5 \mu \mathrm{l}$ of EXPRESS qPCR Supermix with Premixed ROX (Invitrogen, Carlsbad, Cal- 
Table 2. MCPyV detection in each organ from autopsy cases by PCR

\begin{tabular}{|c|c|c|c|}
\hline Organs & Sample number & Single PCR & Real-time PCR \\
\hline Skin & $15[14]$ & $8(53)[8 / 14]$ & {$[0.00031-0.015]$} \\
\hline \multicolumn{4}{|l|}{ Endocrine system } \\
\hline Thyroid gland & $36[5]$ & $2(6)[0 / 5]$ & $0.00074-0.0010$ \\
\hline Adrenal gland & $33[5]$ & $9(27)[0 / 5]$ & $0.00026-0.023$ \\
\hline \multicolumn{4}{|c|}{ Hematopoietic system } \\
\hline Lymph node & 3 & $0(0)$ & ND \\
\hline Thymus & 1 & $0(0)$ & ND \\
\hline Spleen & $37[9]$ & $3(8)[1 / 9]$ & $0.00090-0.0062[0.00090]$ \\
\hline Bone marrow & $36[9]$ & $6(17)[0 / 9]$ & $0.0017-0.083$ \\
\hline \multicolumn{4}{|l|}{ Aerodigestive tract } \\
\hline Salivary gland & 2 & $0(0)$ & ND \\
\hline Tongue & $10[4]$ & $0(0)[0 / 4]$ & $\mathrm{ND}$ \\
\hline Esophagus & $33[6]$ & $5(15)[1 / 6]$ & $0.00047-0.029[0.0021]$ \\
\hline Stomach & $32[7]$ & $3(9)[1 / 7]$ & $0.0015-0.039[0.039]$ \\
\hline Intestine & $34[9]$ & $6(18)[1 / 9]$ & $0.00040-0.22[0.011]$ \\
\hline Liver & $35[9]$ & $3(9)[2 / 9]$ & $0.0060[0.00062-0.0010]$ \\
\hline Gallbladder & $4[1]$ & $1(25)[1 / 1]$ & {$[0.012]$} \\
\hline Pancreas & $37[7]$ & $2(5)[0 / 7]$ & $0.015-0.20$ \\
\hline \multicolumn{4}{|l|}{ Circulatory system } \\
\hline Heart & $35[3]$ & $5(14)[0 / 3]$ & $0.00026-0.042$ \\
\hline Aorta & 26 & $1(4)$ & 0.0036 \\
\hline \multicolumn{4}{|l|}{ Respiratory tract } \\
\hline Lungs & $36[7]$ & $3(8)[0 / 7]$ & $0.00050-0.0013$ \\
\hline \multicolumn{4}{|l|}{ Genitourinary } \\
\hline Kidney & $39[11]$ & $2(5)[1 / 11]$ & $0.00084-0.0064[0.0063]$ \\
\hline Bladder & $28[4]$ & $3(11)[1 / 4]$ & $0.00035-0.036[0.0013]$ \\
\hline Ovary & $8[1]$ & $0(0)[0 / 1]$ & ND \\
\hline Uterus & 11 & $0(0)$ & ND \\
\hline Prostate & 18 & $2(11)$ & $0.0056-0.011$ \\
\hline Testis & $21[4]$ & $2(10)[0 / 4]$ & $0.00052-0.036$ \\
\hline Cerebrum & $1[1]$ & $0(0)[0 / 1]$ & ND \\
\hline Skeletal muscle & $1[1]$ & $0(0)[0 / 1]$ & ND \\
\hline Total & $572[117]$ & $66(12)[17 / 117]$ & $0.00026-0.22[0.00031-0.039]$ \\
\hline
\end{tabular}

$\mathrm{ND}=$ Not done. Figures in parentheses indicate percentages and figures in square brackets frozen sample.

if., USA), $240 \mathrm{nmol} / \mathrm{l}$ of fluorescein-labeled locked nucleic acid hydrolysis probe 22 (5'-TGGTGGAG-3') from a Universal Probe Library (Roche Diagnostics, Basel, Switzerland), and $0.9 \mu \mathrm{mol} / \mathrm{l}$ of a primer in the final volume of $10 \mu \mathrm{l}$. The same primer sequences were used for PCR and real-time PCR. Locked nucleic acid probe 22 was used for viral DNA detection. Thermal cycling consisted of incubation for $2 \mathrm{~min}$ at $50^{\circ}$ with an initial denaturation for $10 \mathrm{~min}$ at $95^{\circ}$ followed by 40 cycles of denaturation for $15 \mathrm{~s}$ at $95^{\circ}$ and annealing for $1 \mathrm{~min}$ at $60^{\circ}$, as previously described [9]. The ratio of the virus was determined using the virus signal in a positive MCC sample as the reference. Thresholds were plotted against each standard sample. All reactions of samples and the controls were performed in triplicate, and the average was reported. The MCPyV DNA ratio in each sample was determined based on the corresponding standard curves.

Detection of MCPyV in Human Tissues Using PCR

\section{Results}

\section{Prevalence of MCPyV-DNA in Autopsy Cases}

The results of the analyses of tissues from the autopsy cases are shown in table 1. MCPyV-DNA was present in more than one organ, and MCPyV infection was detected in more than $70 \%$ of the adults, but neither the fetus nor the infant appeared to be infected. The incidence of $\mathrm{MCPyV}$ infection was 2-fold higher in men compared with women, indicating a significant difference $(p=0.004)$.

\section{MCPyV-DNA Detection in Non-Tumor Tissues}

We tested the DNA from 572 human tissue samples (table 2). The sample set included samples of the normal 
Table 3. MCPyV detection in benign and malignant tumors from autopsy cases by PCR

\begin{tabular}{llll}
\hline Tumor & Total & $\begin{array}{l}\text { Single } \\
\text { PCR }\end{array}$ & $\begin{array}{l}\text { Real-time } \\
\text { PCR }\end{array}$ \\
\hline $\begin{array}{l}\text { Hepatocellular carcinoma } \\
\text { Lung cancer }\end{array}$ & 4 & 0 & ND \\
$\quad$ SCC: 2, adenocarcinoma: 1) & 3 & 0 & ND \\
Papillary thyroid cancer & 2 & 0 & ND \\
SCC of tongue & 1 & 0 & ND \\
SCC of larynx & 1 & 0 & ND \\
Intrahepatic cholangiocarcinoma & 1 & 0 & ND \\
Pancreatic cancer & 1 & 0 & ND \\
Gallbladder cancer & 1 & 0 & ND \\
Rectal carcinoid & 1 & 0 & ND \\
Liver metastasis of rectal carcinoid & 1 & 0 & ND \\
Malignant lymphoma & 1 & 0 & ND \\
Ectopic pancreas of jejunum polyp & 1 & 1 & 0.0018 \\
Endometrial polyp & 1 & 0 & ND \\
Myoma uterus & 1 & 0 & ND \\
Colon adenoma & 2 & 0 & ND \\
\hline Total & 22 & 1 & \\
\hline
\end{tabular}

$\mathrm{ND}=$ Not done; $\mathrm{SCC}=$ squamous cell carcinoma.

skin, the endocrine system (thyroid gland and adrenal grand), the hematopoietic system (lymph node, thymus, spleen and bone marrow), the aerodigestive tract (salivary gland, tongue, esophagus, stomach, intestine, liver, gallbladder, and pancreas), the circulatory system (heart and aorta), the respiratory tract (lungs), the genitourinary system (kidney, bladder, ovary, uterus, prostate and testis), the cerebrum, and the skeletal muscle. The ratio range of real-time PCR was $0.00026-0.22$, and the median was 0.0021 . Eight out of the 15 skin samples were positive for $\mathrm{MCPyV}$, indicating the high prevalence of $\mathrm{MCPyV}$ infection in skin. However, the quantitative real-time PCR ratio was not significantly higher in the skin relative to the other tissues (fig. 1). Interestingly, the frequency of $\mathrm{MCPyV}$ infection of the adrenal gland was higher than that of any other tissue sample except for skin samples. More detailed information is provided in table 2.

\section{MCPyV-DNA Detection in Benign and Malignant \\ Tumor Tissues from Autopsy Cases}

The ectopic pancreas of one jejunum polyp was positive for MCPyV-DNA, whereas the remainder of the tumor tissues was found to be negative for MCPyV-DNA (table 3).

\section{Discussion}

In this study, we used PCR to investigate whether $\mathrm{MCPyV}$ was present in a large variety of human tissue samples. The possibility of contamination is unlikely as the ultrapure water-negative controls were consistently negative. As previously reported [2-8], PCR revealed MCPyV-DNA in many types of human samples, particularly skin samples. Loyo et al. [7] reported real-time PCR data showing MCPyV-DNA in the liver and urinary bladder of more than $50 \%$ of their tested samples; our level of detection was much lower (liver, 9\%; urinary bladder, $11 \%)$. However, the high prevalence of MCPyV-DNA in the skin samples $(53 \%)$ in our study corresponds to the presence (48\%) of MCPyV-DNA reported by Loyo et al. [7]. This appears to indicate that MCPyV has more affinity for the skin compared with other organs. Some reports $[6,7]$ have indicated the presence of MCPyV in nonneoplastic and neoplastic skin samples; we also detected $\mathrm{MCPyV}$ in many non-neoplastic skin samples. Therefore, we speculate that $\mathrm{MCPyV}$ is latent in the skin.

Whilst reference MCC samples had the highest levels of MCPyV, low levels of MCPyV were present in a wide variety of the human tissues. The MCPyV-DNA ratio of non-neoplastic human tissues relative to the reference MCC ranged from 0.0026 to 0.22 , indicating that organs positive for MCPyV-DNA had lower viral loads than the MCC sample.

Moreover, we examined 22 benign and malignant tumors, but only the ectopic pancreas of one jejunum polyp was positive for MCPyV-DNA and had CM2B4 (MCPyV-LT)-positive lymphocytes. It is possible that $\mathrm{MCPyV}$ is not associated with tumors other than MCC tumors, and lymphocytes are latently infected with MCPyV. A recent study [10] reported a prevalence of $22 \%$ of MCPyV sequences in the buffy coats of healthy blood donors. Our study detected MCPyV in many organs, but some of these results may be because of MCPyV in blood vessels or infiltrating lymphocytes. Although only 1 fetus and 1 infant were included in this study, it appears that $\mathrm{MCPyV}$ infection may not occur during the fetal period or early infancy. Chen et al. [11] indicated a $9 \%$ prevalence of MCPyV-IgG among children aged 1-4 years; this was increased to $35 \%$ among those aged $4-13$ years. They concluded that $\mathrm{MCPyV}$ primary infections occur during childhood. To confirm whether infants are infected, additional studies are required. Schrama et al. [12] reported that $249(76.9 \%)$ of 324 male and $268(85.3 \%)$ of 314 female MCC patients were MCPyV positive. The data from the present study indicate that the prevalence of $\mathrm{MCPyV}$ in- 
fection is significantly higher among men $(86 \%)$ compared with women $(38 \% ; \mathrm{p}=0.004)$. This association of $\mathrm{MCPyV}$ status with gender has not been reported previously, and more studies are required to confirm the higher prevalence of MCPyV among the men of Tottori Prefecture (West Japan).

The possibility of contamination is unlikely as the water controls were consistently negative, and the single PCR assay was reconfirmed by real-time PCR assay at two different time points.

The mechanism by which the infection is spread remains unknown. However, it is obvious that the mere presence of MCPyV-DNA is not sufficient for malignant transformation.

In conclusion, the presence of MCPyV-DNA in human non-neoplastic tissues such as the skin, esophagus, lung, liver, intestine, and urinary bladder samples was confirmed by PCR analyses performed. This study is the first to demonstrate the presence of MCPyV-DNA in the fol- lowing organs and tissues: thyroid gland, adrenal gland, spleen, bone marrow, stomach, gallbladder, pancreas, heart, aorta, kidney, prostate, and testis. Furthermore, it is the first to report its absence in the lymph nodes, thymus, tongue, ovary, uterus, cerebrum, and skeletal muscle tissues. Real-time PCR revealed an extremely low viral load in $\mathrm{MCPyV}$-positive human organs and tissues. These detailed data regarding the prevalence of MCPyV-DNA in non-neoplastic human tissues are important and provide valuable insights for further studies of $\mathrm{MCPyV}$ infection and MCPyV-related diseases.

\section{Acknowledgments}

We thank Dr. K. Shomori and Dr. T. Shiomi, Division of Organ Pathology, Faculty of Medicine, Tottori University, for their kind provision of autopsy samples.

\section{References}

- 1 Feng H, Shuda M, Chang Y, Moore PS: Clonal integration of a polyomavirus in human Merkel cell carcinoma. Science 2008;319: 1096-1100.

-2 Gaynor AM, Nissen MD, Whiley DM, Mackay IM, Lambert SB, Wu G, Brennan DC, Storch GA, Sloots TP, Wang D: Identification of a novel polyomavirus from patients with acute respiratory tract infections. PLoS Pathog 2007;3:e64.

- 3 Bialasiewicz S, Lambert SB, Whiley DM, Nissen MD, Sloots TP: Merkel cell polyomavirus DNA in respiratory specimens from children and adults. Emerg Infect Dis 2009; 15:492-494.

4 Goh S, Lindau C, Tiveljung-Lindell A, Allander T: Merkel cell polyomavirus in respiratory tract secretions. Emerg Infect Dis 2009;15:489-491
5 Katano H, Ito H, Suzuki Y, Nakamura T, Sato Y, Tsuji T, Matsuo K, Nakagawa H, Sata T: Detection of Merkel cell polyomavirus in Merkel cell carcinoma and Kaposi's sarcoma. J Med Virol 2009;81:1951-1958.

-6 Foulongne V, Kluger N, Dereure O, Mercier G, Moles JP, Guillot B, Segondy M: Merkel cell polyomavirus in cutaneous swabs. Emerg Infect Dis 2010;16:685-687.

$\rightarrow 7$ Loyo M, Guerrero-Preston R, Brait M, Hoque MO, Chuang A, Kim MS, Sharma R, Liegeois NJ, Koch WM, Califano JA, Westra WH, Sidransky D: Quantitative detection of Merkel cell virus in human tissues and possible mode of transmission. Int J Cancer 2010;126:2991-2996.

-8 Teman CJ, Tripp SR, Perkins SL, Duncavage EJ: Merkel cell polyomavirus (MCPyV) in chronic lymphocytic leukemia/small lymphocytic lymphoma. Leuk Res 2011;35:689692.

-9 Kuwamoto S, Higaki H, Kanai K, Iwasaki T, Sano H, Nagata K, Kato K, Kato M, Murakami I, Horie Y, Yamamoto O, Hayashi K: Association of Merkel cell polyomavirus infection with morphologic differences in Merkel cell carcinoma. Hum Pathol 2011;42:632640 .
-10 Pancaldi C, Corazzari V, Maniero S, Mazzoni E, Comar M, Martini F, Tognon M: Merkel cell polyomavirus DNA sequences in the buffy coats of healthy blood donors. Blood 2011;117:7099-7101.

11 Chen T, Hedman L, Mattila PS, Jartti T, Ruuskanen $\mathrm{O}$, Soderlund-Venermo M, Hedman K: Serological evidence of Merkel cell polyomavirus primary infections in childhood. J Clin Virol 2011;50:125-129.

12 Schrama D, Peitsch WK, Zapatka M, Kneitz H, Houben R, Eib S, Haferkamp S, Moore PS, Shuda M, Thompson JF, Trefzer U, Pfohler C, Scolyer RA, Becker JC: Merkel cell polyomavirus status is not associated with clinical course of Merkel cell carcinoma. J Invest Dermatol 2011;131:1631-1638. 